\title{
Questions and a myriad answers: Coming together and drifting apart in the historical sciences
}

\author{
Dan C. Baciu
}

There is no end to the questions you can ask, and no end to the answers you can give. Where then, in this space of endless possibilities, can research begin; and how can researchers be expected to reach any consensus on what are useful question-answer-pairs? This present article recounts the story of Sigfried Giedion and Bruno Zevi. Space, Time and Architecture, a book printed at Harvard University, ties the fates of the two Europeans. Giedion is the author, Zevi is a reader surrounded by a transatlantic group of followers. Initially a strong promoter of Giedion's book, Zevi later changed his mind and went on to propose his own, divergent theory of space and architecture. Zevi and Giedion's story of coming together and drifting apart is not unique. We all live in a world in which ideas spread and diversify as people search for questions and a myriad answers.

\section{Students in Chicago}

Two charming Harvard students walk down the streets and avenues of Chicago. One of them is only an undergraduate, but he is a local. He finds delight in the fresh feel of the wind that comes down from Lake Michigan. ${ }^{1}$ Yet, when the wind passes through the center of the city, it encounters towering skyscrapers that break with the gently curved horizons of the Great Lakes and Plains. The wind swirls. The air masses begin to rotate and rise between hundreds of identical windows. During occasional windstorms, countless eyes watch this spectacle in amazement. Sharp reflections on the glass both veil and reveal urban life, while withered brick walls convey a sense of time. Something surprising is then observed. Older skyscrapers, through their large, shiny windows and simplicity of design, often appear more modern than their newer neighbors that are more heavily clad in ornate terracotta. It could seem that a mighty storm in this Windy City has also turned architectural history upside down: The oldest buildings shine with modernity, while newer buildings appear withered and antique. The convoluted history that has given rise to this architecture fascinates our two students. Let me also say that the year they visit the city is not just any year; it is 1941. World War II has just shattered everyone's identity. And so, our two protagonists are in search of their own origins. Along the way, one of them rediscovers his own city; the other is about to rediscover the history of modern art.

Art is all about crafts and possibilities, or at least, that's what the word's etymology tells us. Art is different from science. A scientist tells you, "Look what I know based on experience." The artist replies, "Look what I can do, it might broaden your experience." This also means that art and science work best in unison. Together, art and science create new possibilities and new knowledge, and they break the ground for new ways of life. America and Chicago are relevant in this context. America is still known as the land of unlimited possibilities, and Chicago is one of the places where these possibilities were most openly tested. The American way of life and Chicago's skyscrapers thus entered the history of modern art. 
Already towards the end of the 19th century, Chicago's skyscrapers were celebrated as unique artistic expressions. Western architects and journalists witnessed the birth of a distinctive movement they called the "Chicago school," but appreciation for the architecture built in the West could also come from some of the greatest architectural centers of the East, for example from New York City. When Columbia University opened a school of architecture in New York, A.D.F. Hamlin was the first professor to teach architectural history, and he became commonly recognized as one of the founding figures of architectural history in the United States. Hamlin published the first American textbook of architectural history. In this book, he discussed the "Chicago school" in one of the concluding chapters. ${ }^{2}$

In Hamlin's textbook, the "Chicago school" epitomized "the untrammeled freedom of art in a land without traditions." With the term "traditions" Hamlin referred to Egyptian, Greek, and Roman art. In line with other historians, he described how an entire sequence of ancient Mediterranean empires copied each other's buildings and art; and the Italian Renaissance and the French École des Beaux Arts later copied this art and architecture, as well. However, Hamlin wished to see the West free from this millennia-old tradition.

There can be no doubt that Hamlin appreciated ancient Mediterranean art and architecture. As an American professor born in Constantinople, he loved the Mediterranean, and he kept traveling east. His many watercolors show his fascination with what he saw in old traditions. Nevertheless, Hamlin understood that architects in the West were free to inspire themselves in local, vernacular architecture. They were free to start something new; and they were free to be proud of scientific advancement. In Chicago, small vernacular houses evolved into skyscrapers. For Hamlin, this evolution meant something important: The United States was leading the way in both art and science. Hamlin also spoke of the "American school" as something that had come out of the developments in the West. ${ }^{3}$ However, Hamlin's book and articles date from around 1900. By 1941, history had been utterly rewritten: American historians no longer used the term "Chicago school" for skyscrapers but for suburban mansions. The skyscrapers continued to evolve, and they evolved into suburban sprawl. As one could expect, the Europeans who immigrated during World War II had not quite gotten so far. They believed that a search for the roots of modern American art could not leave Chicago's tall buildings unseen.

John A. Holabird, who guides us this unforgettable day of 1941, takes the role of a local who rediscovers his own culture. ${ }^{4} \mathrm{He}$ was born in a legendary family of architects. The Tacoma and Marquette buildings, the Gage group, and the southern half of the Monadnock block are only four of his grandfather's earliest achievements. These buildings united art and science and reinvented Chicago's urban life. In contrast, later designs opted for more abundant decoration and smaller windows. That's when the "art deco" took over. But grandfather Holabird died when John was three years old, too fragile an age to understand and remember the whole history of architecture. Yet, John remembered that his grandfather called him "starry eyed."5 The stars would still show at a later age. Beginning with 1941, John would be surprised to witness how Europeans and Americans alike rediscovered his grandfather's skyscrapers. ${ }^{6}$ They rediscovered Chicago's central district, the "Loop." They all rediscovered the history of modern art.

The search for the identity of the student whom John Holabird guided through Chicago leads us deeper into student life at Harvard. Our eyes open onto an entire transatlantic community held together by the ardent desire to rethink art and architecture. In this context, it must be remembered that Harvard had ties to Chicago early on. In 1903, William James, a famous philosopher and Harvard professor, asserted the existence of a "Chicago school of thought;" and in the 1920s, his student Ezra Park eventually became a founding figure for the "Chicago School of Sociology." The ties were never lost, but in 1941, 
they were breathing new life through an entirely new source. European immigrants found much fascination with the West, and in a voluminous book printed just then, a Swiss historian boldly titled one of his chapters "The Chicago School." At Harvard, fascination with this book was spreading through word of mouth. What's nice is that any student who liked this book could have been the one to follow John Holabird through Chicago. For certain, it is known that an Italian immigrant read and liked the text. He had short, dark hair, a sharp nose, brown eyes, and thick, alluring eyebrows (Fig. 1). You heard his name, by now: He is Bruno Zevi.

Bruno Zevi. Image source and copyright: Bruno Zevi Archive.

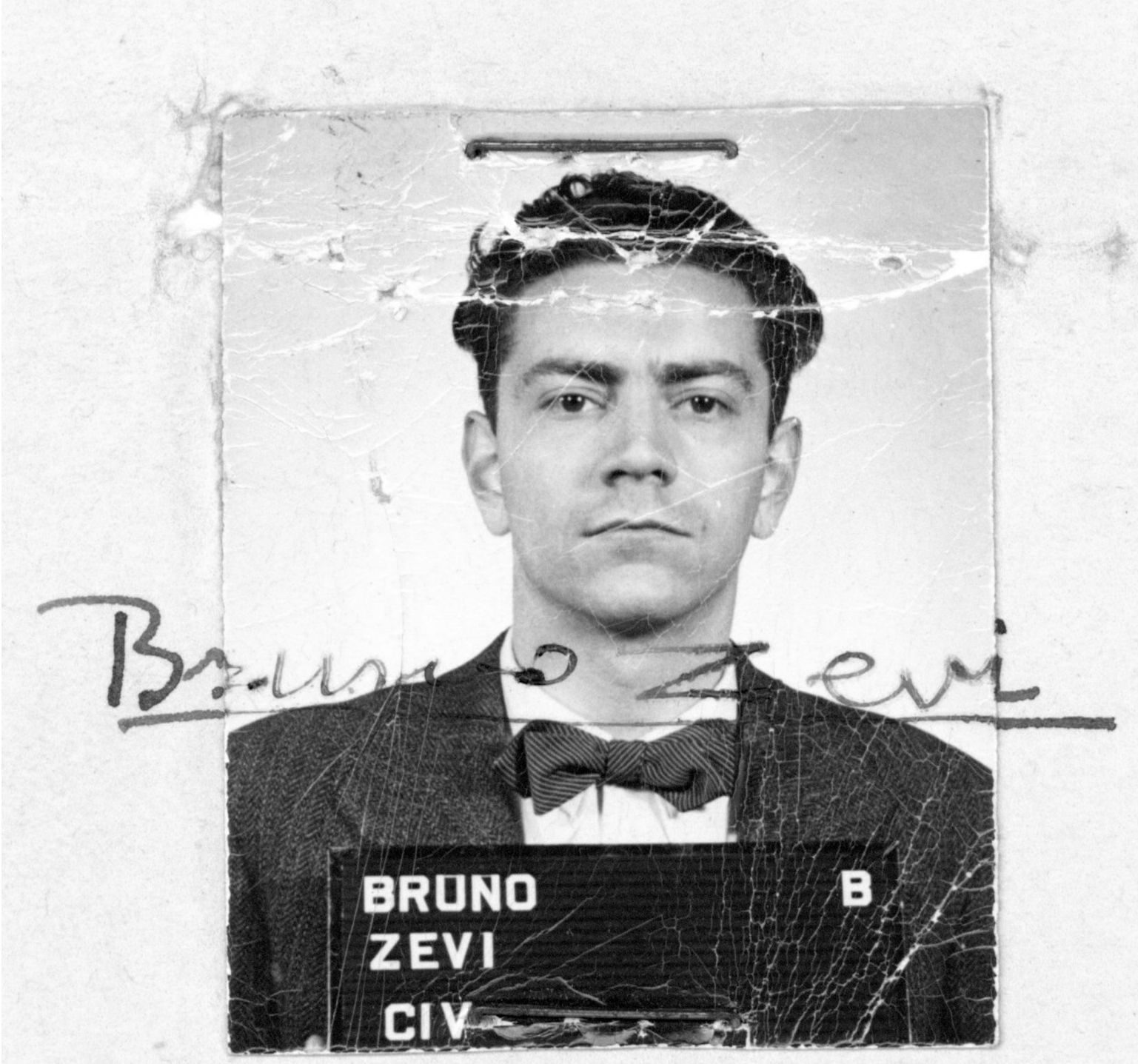


As Italian speaker, Zevi could have liked Chicago's Italian neighborhoods and newspapers. However, he found most interest in the Chicago school-although the Chicago school was never destined to become a film legend comparable for example to the mafia boss, Al Capone. Why did the Europeans wish to see the Chicago school, in particular? John Holabird was at first surprised at his friend's wish. He frankly did not know what the Chicago school was. His friend said, "here I have a book about the Chicago school." Only then, they went to see the buildings.

In their hands, the two youngsters weigh a first edition of a now legendary book they've brought from Boston. What makes them look somewhat odd is that John is a likeness of his father, a well-known local architect, but he comes as a tourist. In addition, their book is not the kind of possession you would normally like to carry along while touring a city. With its heavy, glossy paper, even the first edition was rather bulky. Admittedly, the book featured a chapter on Chicago, or more specifically, on the Chicago school. But what makes this chapter so special for the two visionaries?

Our two students, local and foreign, would walk down narrow street canyons and come to stand in front of steel giants of the machine age. Vertical lines guide their marveled eyes up into the sky. Their hands wish to touch the hidden steel skeletons. Other people feel dwarfed in front of such edifices, and too often, steel is associated with mechanization, weapons, and war. Right as our two protagonists walk and talk, all steel goes into human selfdestruction, which is an imminent threat to young men like them. For John, America would enter the war by the end of the year, and his father and grandfather were both military men. John himself would become one of too many smiling faces of young Americans most of whom passed away in mid-September 1944. They parachuted and were shot in something that historians later called no more than a failed war maneuver. In contrast, John was proud his whole life for having brought back a silver star. He thought he was honored simply because he survived. ${ }^{7}$ But he, Zevi, and their Harvard friends saw something quite different in the steel giants. Their book presented Chicago's skyscrapers as meaningful achievements, calling them by their old and true name "Chicago school." These edifices had been built during the Gilded Age that began after the end of the Civil War. Historically, that's when the Great Fire left Chicago in ashes. The skyscrapers of the ensuing two decades were meaningful achievements because they showed that steel could be used in a constructive way. Once Word War II was over, it was Zevi and Holabird's generation who would rethink Europe and modernize the United States. For them, the Chicago school was a school one could learn from. In 1941, not everyone agreed.

The book that led John Holabird and his Harvard friend through Chicago could seem an odd choice for a city tour not only because it was bulky, but also because it was written by a foreigner who did not actually know the city. Was "Chicago school" really the best name for the skyscrapers? Local historians opposed this view. Why did John not simply ask his father to tour them? True, their bulky book was published by Harvard University Press, but Sigried Giedion, the book's author, barely knew the city. He was offered a one-year position in English at Harvard, which first brought him to the United States in 1939. And Giedion did not stay long. In 1941, when his book was printed, he was already back in Switzerland. What then made the content of Giedion's book better than, say, entertaining oneself with the 1933 production of King Kong climbing the just-completed Empire State Building?

Giedion may have been a foreigner to the United States, but when it came to his research in Chicago, he was both resolute and lucky. At age fifty, he visited Chicago in January 1939. The long journey from Boston did not stop him; the icy lake wind did not frighten him. He visited Thomas Tallmadge, the historian of the suburban "Chicago school." He nicknamed him Tom. He also visited Holabird \& Root, the company once founded by 
John's grandfather. There, Giedion directed his main attention to an elderly architect, Frank Long, who had joined the company in its early heydays, during the construction boom of the 1880s. Long was a sensation for a foreign historian. He lived just long enough to tell Giedion a story he would never forget. In the opening chapter of Space, Time and Architecture, ${ }^{8}$ Giedion's book of 1941, one can find some of Long's words. They are only gently reformulated. The most important contribution that Giedion made to the story he heard from Long is that he integrated it into the admittedly broader context of his magnum opus. ${ }^{9}$

The story of the Chicago school, as pictured in Space, Time and Architecture is dramatic. Two fronts clash. On one side is the Chicago school; on the other is revivalist architecture. The Chicago school stays for an entire generation of Western architects who wish to unite art and science. They inspire themselves in vernacular architecture and in the balloon frame, an American type of wooden construction. Along the way, plain vernacular decoration is elevated to art, and the balloon frame becomes the steel frame of early skyscrapers (Fig. 2). In contrast, revivalist architecture brings European traditions to the United States. Revivalist architecture is a surrogate of ancient Mediterranean art now ruthlessly displacing more local artistic expressions on a new continent. Hamlin, the Columbia professor mentioned before, portrayed revivalism as heartless display of decoration. ${ }^{10}$ The clash between Chicago school and revivalism ended in drama, and a drama that was painful to modernists such as Giedion and Zevi. The Chicago school was shattered whereas revivalism emerged victorious. In the aftermath, advocates of the early Chicago school became isolated. Their voices went unheard.

Sigfried Giedion’s Lecture Slides. A-D: Chicago School. E: Revivalism.
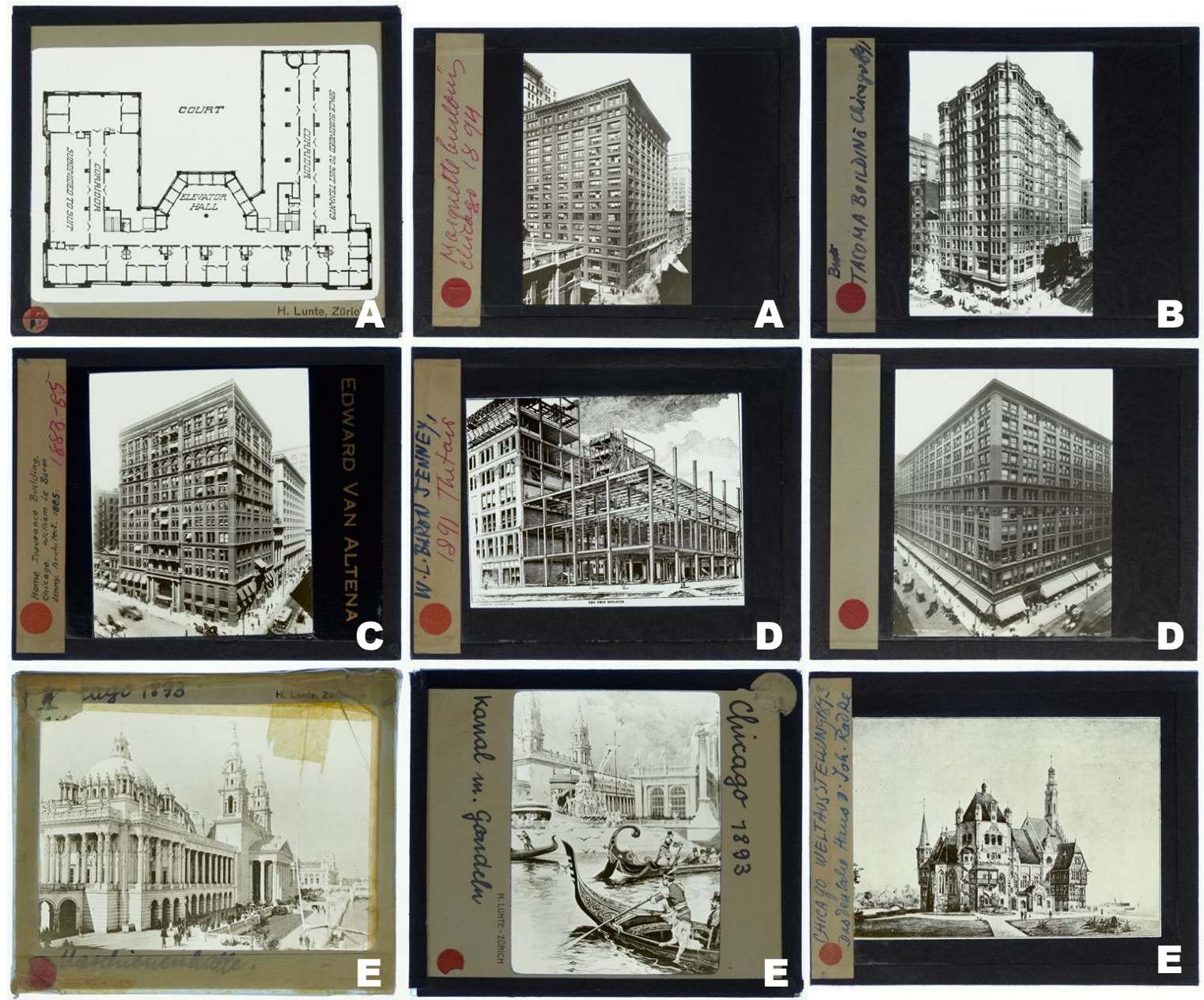
In Space, Time and Architecture, Giedion recounts an encounter he had in Chicago with one of these lonely, unheard voices. He described the rather ironical behavior of this isolated architect who had been part of the catastrophic clash between Chicago school and revivalism back then, in the 1890s. Now, this old practitioner was limited to citing the philosopher William James from memory rather than building actual buildings. This lonely architect, mentioned in Giedion's Space, Time and Architecture is no fictional character. His real name is Frank Long. ${ }^{11}$

The final demise of the Chicago school came only a few months after Giedion visited the city. When he returned to Harvard, the first thing he found on his desk was a long letter from Long (a letter he would later copy from); and he would rush to answer this letter. However, Long would no longer respond. He passed away. Only shortly thereafter, historians who believed that the Chicago school never built skyscrapers attacked Giedion. However, Long would no longer be on his side as a witness of the old ways. Giedion would eventually be denounced as someone who forged history fitting it into a narrative tweaked to serve his own agenda but devoid of historical evidence. Already in 1939, the National Council of Architectural Registration Boards wrote Giedion, warning that his idea of the Chicago school was a "monumental error."12 Ironically, Long was older than the National Council of Architectural Registration Boards. This makes Long a better historical source. Thus, it comes that, in 1941, Giedion's book was unique because it drew on the oral history that Long had shared. Space, Time and Architecture returned to the historiography of the Chicago school once put forth by A.D.F. Hamlin and remembered by old practitioners who had been part of the events. Giedion cited Hamlin, and he mentioned Long and William James, but it was all to no avail. The old Chicago school was pictured as a "myth." Almost a century later, Giedion's book is unique once again, because it provides a window into the history of the old and true Chicago school, the Chicago school that has been forgotten and erroneously denounced by vociferous historians who had the advantage of being somewhat more local to the city.

Zevi was one of the architects who rarely questioned the authenticity of Giedion's sources. Maybe, he simply trusted, or maybe, his and Giedion's stories were too tangled, anyway. Giedion was at Harvard between 1938 and 1939, Zevi from 1940 to 1942. Giedion was a lecturer, Zevi a student. In 1941, when Space, Time and Architecture was published, Giedion was gone, but Zevi had arrived. Eventually, Zevi returned to Europe, as well. He served as translator on the side of the allied forces. This experience must have given him a sense of purpose. After the war ended, he did not let go of the past. Indeed, he made a statement that unites his education at Harvard with service as translator and with his new work as architectural historian. In a magazine article, he stated that he had begun his first big book by "translating"13 Giedion's Space, Time and Architecture into Italian. When contextualized within Zevi's biography, these words make a bold statement: Here comes Bruno Zevi, a freshly minted historian, a winner of the war. He is a student of Sigfried Giedion's.

It is possible that Zevi's motivation for stepping behind Giedion was of complex nature. Likely, this position allowed him to advertise for his new book as a better version of Space, Time and Architecture. Zevi's exuberant approval of Giedion was sometimes paired with equally strong objection, if not resentment. The tension in Zevi's mind could not be stronger. In one essay, he managed to crown and behead Giedion in no more than two sentences:

"All of us always have in mind [Giedion's] Space, Time and Architecture, and we continually find in it elements and data useful to our research, but to recognize its 
superior scientific qualities does not mean that we agree with its historical theses.

Space, Time and Architecture is a splendid book, but a misleading one."14

This tension is much felt when it comes to historiography. Giedion's book chapter "The Chicago School" and Zevi's Italian "La Scuola di Chicago" are very similar in terms of content. However, Zevi placed his text into a book that had a rather different outlook. This difference is best recognized in the book titles. Zevi's title Storia dell'Architettura Moderna ${ }^{15}$ comes closer to "History of Modern Architecture." At first, this may just sound like a more generic title. However, the absence of "space" or "time" hints at a deeper undercurrent and divergent views on the foundations of modern art.

\section{Space and Time, Matter and Energy}

Giedion's book, Space, Time and Architecture, likely owes its title to another book published 20 years earlier, Space and Time, Matter and Energy. ${ }^{16}$ This earlier book is a layman's introduction to the physics of spacetime and to the theory of relativity. The title choice is easy to understand. The first word pair, "Space and Time," stands for Hermann Minkowsky's representation of space and time as four-dimensional spacetime. The second word pair, "Matter and Energy," stands for Albert Einstein's equation $e=m c^{2}$. The author's brilliant idea was to explain spacetime first, because it is easier. Only then, he continued to Einstein's equation and explained why energy $e$ and mass $m$ really are one and the same thing. From this physics perspective, this 1921-title is easy to interpret, and not only this one, but also Giedion's 1941-title. To obtain Giedion's title, there is only one tiny and playful step to do: "Matter and Energy" are contracted into "Architecture." Well, if matter and energy are one and the same thing, why not call this thing architecture?

Before finding this final title, Giedion had several others in mind. Initially, he thought of something like "The Life of Architecture." Most titles were short-lived. The final choice came as a flash, when the book was already written. However, if this final title really were meant to be playful, as it seems, would it not have been fun to write down how it came into being?

Historiography must always make choices, what to tell, what not to tell. There are endless questions to ask and endless answers to give. There is no way to summarize everything in one single volume and put it down forever. Some things are better put into words, but others better remain unspoken.

What applies to the historical sciences, applies more broadly to most other sciences. There are infinite ways to theorize about reality, and there are infinite observations one can make. Gold's theorem ${ }^{17}$ states that there is no preferred way to make a match between theory and observation - of course, unless one has preferences. For example, one can hold that the real value of science is that it can inform present-day action. Then again, Einstein's theory of relativity mentioned before shows just how difficult it is to recognize the utility of ideas. Initially, Einstein's theory found little application, although it fascinated artists.

And so it came that Felix Auerbach, a German physicist wrote a layman's introduction to spacetime and relativity. Auerbach was a magnet of artists. He had his portrait done by Edward Munch, painter of "The Scream." Many artists read Auerbach's book and lauded it. In 1921, the book was eventually published under the title mentioned above. Just around this time, Auerbach employed Walter Gropius, an architect of the German vanguard, to build his house as an experiment in modern architecture. Until the early 1930s, this house served as a meeting point for artists, but then, the Nazi party seized power over Germany. Gropius 
emigrated to become the head of the school of architecture at Harvard. There, he employed Giedion. However, Auerbach was unable to travel. He and his wife are recorded to have committed suicide. The news must have shocked everyone. The title Space, Time and Architecture tells these stories in words, but without really spelling them out. ${ }^{18}$ Maybe it was better, not to do so.

Giedion wrote an accurate history of the Chicago school, but he did not put down the name of his informant, Frank Long. Giedion also explained his view on the physics of spacetime. He mentioned the theory of relativity, and its author Albert Einstein. Giedion went on to write about artists who had inspired themselves from Einstein's theory of relativity. Yet, he did not write explicitly about all terrors of war. On this basis, Zevi only partially understood the story. He did agree that the concept of spacetime influenced the thinking of artists and architects. However, his views eventually drifted apart. In 1979, he gave a lecture "Architecture and Einstein's Space-time." In this lecture, Zevi called Giedion's interpretation of spacetime "rather rough and approximate from a scientific viewpoint." Zevi also wrote a letter to Einstein, asking whether the concept of spacetime applied to art as envisaged by Giedion. Einstein disapproved, although he wished his answer to be kept confidential. Ironically, the four-dimensional representation of spacetime that Zevi and Giedion discussed is primarily Minkowsky's, not Einstein's. And Minkowsky and Einstein had something that made them similar to Giedion and Zevi. Once, they had been professor and student.

Eventually, Zevi came up with new ways of thinking about space. Next to Storia dell'Architettura Moderna, his book title Architecture as Space: How to Look at Architecture $^{19}$ also stands witness for this different way of theorizing about space, a way less deeply rooted in the physics of spacetime. The memory of Auerbach was lost along the way to new and newer ways of asking questions.

\section{Diversification}

There are at least two ways to explain the differences between Giedion and Zevi. First, one could portray Zevi as a disciple who initially follows his teachers but later wishes to free himself and make his own voice heard. The beauty of this first explanation is that it could easily be turned into a movie. In the movie, one could show all of the myriad causes that led to Zevi's behavior. However, it would remain unclear why disciples need to say something new to become heard, in the first place.

The other explanation is the one that I would like to further discuss here. This latter explanation is less dramatic, but it tells something beautiful about cultural life in general. Rather than focusing on individual causes, this perspective engages with the insights that can be obtained from looking at the big picture. This big picture is unlike the details, and it may at first seem abstract and mathematical, but the benefit is that it reveals a deeper truth that everyone faces.

Divergent historiographies such as Giedion and Zevi's inform our actions in ways that cannot be fully foreseen. History is information about the past. However, this information is used in present, and it is often unclear what present-day actions it informs. The paths from history to present-day action are often so winded that it is unclear which information is the better informant. This question is typically decided in a decentralized way in which many people choose in parallel. The collective of readers decides which is the better historiography.

Under these circumstances, one could propose that there exist differences simply because they can. At the same time, it is evident that different historiographies compete for audiences. It remains to be explained why competitive exclusion does not eventually push all 
but one historiography into oblivion. When the Chicago school clashed with revivalism, one emerged victorious, while the other was "abruptly choked off," as Giedion wrote. If the problem of competitive exclusion is not solved, it must always remain a riddle why competing historiographies such as Giedion and Zevi's continue to co-exist.

The theory of cultural life that I proposed in my recent article in the journal BioSystems explains just this process of diversification. ${ }^{20} \mathrm{With}$ this theory in mind, historians need no longer to imagine Giedion and Zevi as antipodes. Historians need no longer stage animosities between them and illustrate their fights with excruciating close-ups. Giedion and Zevi grew apart because of a natural process of diversification that is part of all life, biological and cultural.

Imagine a cohort of people who reach the ocean. They can decide to sail together in one direction, or they can split up into multiple groups and sail in multiple directions. This latter choice of splitting up is called diversification. Through diversification, our cohort of people is divided into multiple independent units that search the ocean in multiple directions. Diversification is useful when searching things that are broad as the ocean.

The future is always an uncharted ocean of unknowns. Diversification is useful because the future is always ahead of us and we have no choice but exploring it. Diversity is useful towards exploring the future because it allows us to search in multiple directions. As a consequence, biological as well as cultural systems have both developed processes of diversification through which they overcome the problem of competitive exclusion. The important insight here is that diversity exists not only because of the past, but also because of its benefit for the future.

Thus, the study of diversification reveals something rather counterintuitive when it is applied to the contradiction between Giedion and Zevi. In order to understand the differences between the two authors and the co-existence of their historiographies, we need to understand both the past and the future. We need to know that diverse historiographies present us with diverse options for present-day action. Diverse historiographies exist because they provide us with the freedom to inform our modern existence. They allow us to play a role in shaping our immediate and distant futures. With divergent historiographies, we have multiple, independent ways to go.

Author: Dan C. BACIU (ORCID: 0000-0002-0043-5616)

Conference: Apr. 2018. Preprint: Oct. 2020 https://doi.org/10.31219/osf.io/g8d9c

Published in: Dellapiana E., Cassani Simonetti M. (ed). Bruno Zevi. History, Criticism and Architecture After World War II. Milan: Franco Angeli, 2021, 8-21.

\footnotetext{
${ }^{1}$ Susan S. Benjamin, "Oral History of John Augur Holabird" (Chicago: The Art Institute of Chicago, 1993), 106.

${ }^{2}$ Alfred Dwight Foster Hamlin, A Text-book of the History of Architecture (New York: Longmans 1900).

${ }^{3}$ Alfred Dwight Foster Hamlin, "The Influence of the Ecole des Beaux Arts on Our Architectural Education," Architectural Record (April 23, 1908), 241-247.

${ }^{4}$ Masami Takayama, "Good Buildings, Cheap," Interview with John A. Holabird, Proecess 35, (1983), 25.
} 
${ }^{5}$ Susan S. Benjamin, "Oral History of John Augur Holabird" (Chicago: The Art Institute of Chicago, 1993), 1.

${ }^{6}$ Masami Takayama, "Good Buildings, Cheap," Interview with John A. Holabird, Proecess 35, (1983), 25.

${ }^{7}$ Susan S. Benjamin, "Oral History of John Augur Holabird" (Chicago: The Art Institute of Chicago, 1993), 54.

${ }^{8}$ Sigfried Giedion, Space, Time and Architecture (Boston: Harvard University Press, 1941).

${ }^{9}$ Dan C. Baciu, "Sigfried Giedion's Chicago School: A Midpoint in 150 Years of History," OSF Preprints (June 1. 2020).

${ }^{10}$ Alfred Dwight Foster Hamlin, "The Influence of the Ecole des Beaux Arts on Our Architectural Education," Architectural Record (April 23, 1908), 241-247.

${ }^{11}$ Dan C. Baciu, "The Chicago School: Large-scale Dissemination and Reception," Prometheus 2 (Nov. 17. 2019), 20-43.

${ }^{12}$ Dan C. Baciu, "Sigfried Giedion: Historiography and History of Reception on a Global Scale," in Dana Margalith and Iris Aravoth, Ar(t)chitecture (Haifa: Technion Israel Institue of Technology, 2016).

13 "Io non ho fatto altro che tradurre Space, Time and Architecture" Bruno Zevi, "Messaggio al CIAM. Della Cultura Architettonica." Metron 31 (1949), 10.

${ }^{14}$ Bruno Zevi, On Modern Architecture (New York: Rizzoli, 1983), 128.

${ }^{15}$ Bruno Zevi, Storia dell'Architettura Moderna, (Torino: Einaudi, 1950).

${ }^{16}$ Felix Auerbach, Raum und Zeit, Materie und Energie: Eine Einführung in die

Relativitätstheorie (Leipzig: Ordentliche Veröffentlichungen der Pädagogischen LiteraturGesellschaft Neue Bahnen, 1921).

${ }^{17}$ E. Mark Gold, "Language Identification in the Limit." Information Control 10 (1967), 447474.

${ }^{18}$ Dan C. Baciu, "Sigfried Giedion's Chicago School: A Midpoint in 150 Years of History," OSF Preprints (June 1. 2020).

${ }^{19}$ Bruno Zevi, Architecture as Space: How to Look at Architecture (New York: Horizon Press, 1957). Originally published 1948 as Saper Vedere l'Architettura.

${ }^{20}$ Dan Costa Baciu. "Cultural Life: Theory and Emprical Testing” BioSystems 104208 (July 20. 2020). 